\title{
Gender, Ethnicity, and Religion and Investment Decisions: Malaysian Evidence
}

\author{
Mohamed Albaity, PhD \\ Department of banking and finance, faculty of business and accountancy, University of \\ Malaya, Street Address:Jalan Lembah Pantai, City:Kuala Lumpur, Malaysia \\ Mahfuzur Rahman \\ Department of banking and finance, faculty of business and accountancy, University of \\ Malaya, Street Address:Jalan Lembah Pantai, City:Kuala Lumpur, Malaysia
}

Accepted: November 04, 2012 Published: December 04, 2012

Doi:10.5296/jsr.v3i2.2649 URL: http://dx.doi.org/10.5296/jsr.v3i2.2649

\begin{abstract}
This paper examines how the interaction between gender, religion, and ethnic differences influence the key determinants of individual investment behavior, which are different types of risk taking, luck, overconfidence, happiness, maximization, regret, and trust. We find that in gender-ethnic groups there are significant differences among Malaysian Malay and Malaysian Chinese but not among Malaysian Indian. With regard to gender-religion groups there are significant differences among Malaysian Muslims, Christians, and Buddhists but not among Malaysian Hindus. These gender-ethnic and gender-religion groups differ in range of variables such as luck, maximization, overconfidence, trust and risk. In addition, foreign students living in Malaysia were included in the study and we found that there is significant difference between male and females in term of luck and lifetime income risk.
\end{abstract}

\section{Introduction}

Behavioral finance has made advances in explaining the behavior of markets. It focuses on the irrational behavior of the individuals in the economy. Studies found that culture and beliefs influence how individuals make economic decision as well as investment decisions (Hong et al., 2004; Huang, 2008; Chui et al., 2010; Beugelsdijk and Frijns, 2010; Guiso et al. 2006 and 2008). In the past, the relationship between gender and risk taking behavior has been studied quite frequently. One particular aspect that has received a lot of attention in recent years is the significance of difference in risk taking behavior by gender as a determinant of household investments (Campbell, 2006). For instance, Jianakoplos and Bernasek (1998) investigate how women are different from men in risk aversion. The authors 
come to the conclusion that women are more risk averse than men. It also indicates that there is a positive relationship between women age and risk aversion. Women hold less risky investment as their age increase than men. Graham, Stendardi, Myers and Graham (2002) found that women are more comprehensive in information processing than men and tend to give more weight to negative information therefore leading them to be more risk averse than men. In addition, it is also well documented that overconfidence bias varies based on gender (Baber and Odean, 2001; Lundeberg, Fox and Puncochar, 1994). Men tend to be more overconfident than women, which can be linked to women's risk aversion behavior in general.

However, individual risk taking behavior is also influenced by regret (Inman and Zeelenberg, 2002; Zeelenberg et al., 1996; Zeelenberg and Beattie, 1997; Zeelenberg, 1999). For example, people tend to avoid regret of making a bad investment or shame of reporting a loss in the future by avoiding risk now which lead to being risk averse investor. In contrast, if people have more than one option, where one is more risky than the others and there is always feedback on the outcome of the riskier option, this could lead to risk seeking. However, researchers document that investors follow the crowd to avoid the feeling of regret where there is a possibility that their decisions prove to be wrong. Personal trust plays such an important role in financial market even though this concept does not fit in to the current financial theory. There is a significant relationship between trust and risk taking (Luhmann, 1979 and Seligmen, 1997). For instance, studies found that perceived risk is inversely related with trust (Siegrest et al., 2000; Sjoberg, 2001; Viklund, 2003; Olsen, 2008). In addition, Guiso et al. (2008) argues that one's trust highly depends on his ethnic origin and religious background indicating the relationship between religion background, ethnic origin and risk taking behavior. In contrast, Alesina, and La Ferrara, (2002) found that there is no significant effect of religious beliefs and ethnic origins on trust. Therefore, it will be interesting to know what relationship exists in Malaysia within its multi racial people along with various religious beliefs. Guiso et al. (2003) and Arrunada(2009) argue that religion has significant influence on the financial choices individuals make. Indeed, in many situation people make investment decision by relying on their luck as well. And they take risk when the situation is more uncertain leading to high outcome. Since some people want to fulfill their desire by the best possible outcome, therefore they love to take risk due to the expectation of higher returns. However, higher income does not guarantee happiness or life satisfaction. The past studies provide mixed result regarding the relationship between income and happiness (Easterlin, 2001; Frey and Stutzer, 2002).

Individual investment puzzle in the economy stems from the fact that most households do not invest their optimal amount of capital despite high returns and significant risk premium. This investment behavior poses a very significant question to us. Traditional finance theory argues that investors' willingness to take financial risks is significantly influenced by investment opportunities and risk aversion (Markowitz, 1995; Sharpe, 1964), whereas behavioral finance have introduced several new factors that affect household financial decisions. Mostly prior research focuses on only one determinant or one area at a time in 
analyzing influential individual characteristics. However, past studies indicate mixed results in establishing the relationship between individual characteristics and households' financial decision may be because behaviors differ from one country to the other depending on culture as mentioned by Guiso et. al. (2003). Previous work on this area focus on the differences between males and females, religions, race, as well as marital status. However, most of the studies either done in US or done in a global scale such as Statman (2008) who studied 22 countries including Malaysia and found that overall there is a difference in all the items who studies except Regret. This study is different from previous study in three folds. First, this study focuses on Malaysia. This is interesting because behavior differ from one country to the other depending on culture as mentioned by Guiso et. al. (2003). In addition, behaviors of different ethnicities can be generalized to other countries with similar ethnicity. Second, Malaysian population consists of three major ethnicities who have their different cultures and religious affiliations. Third rationale is that Malaysian population if composed of four major religions namely, Islam, Buddhism and Hinduism along with Christianity and other minor groups in different religions. It is clear that this entangled society in ethnicity, culture and religion will yield interesting results that help in understanding their behaviors.

More research is clearly needed. To take a step further, this paper therefore, investigate whether there is any significant difference between male and female in terms of risk taking, skill, luck, Happiness, maximization, regret, and trust. We then examine whether individual from different gender-religion background are significantly different in terms of risk taking, skill, believing in luck, Happiness, maximization, regret, and trust. Moreover, we try to identify whether people from different gender-ethnic origin are significantly different in risk taking, skill, luck, Happiness, maximization, regret and trust. Lastly, the relationship between these variables will be investigated whether results confirm previous results or deviate based on the culture and religion.

Our results suggest that there is a significant difference between gender-ethnic groups except Indian in different aspects. In addition, the results indicate that there exists a significant difference between gender-religious affiliations. Moreover, there is a significant difference between gender-nationality groups in one aspect only.

The remainder of this paper is organized as follows. Section 2 reviews the literature on regret, overconfidence, trust, luck and skill, maximization and Happiness or life satisfaction as well as discusses how observable differences in these attributes may affect investment decision making. Section 3 details the data and methods used in this study. Section 4 provides the results and analysis. Section 5 provides concluding remarks with implication for future research.

\section{Literature Review}

Gender and risk tolerance 
Using Myers-Briggs Type Indicator to examine the personality type biases and how it correlates with gender biases in creating better client profile Pompian and Longo (2004) administrated questionnaires to 100 investors. They found that many personality types and both genders are disposed to behavioral finance biases. For example in terms of gender, females are one third more risk averse than males. Moreover, the most risk tolerant males combined with their personality type should invest $100 \%$ in equity base instruments, while the least risk tolerant females combined with their personality type should invest $100 \%$ in fixed income instruments. Jianakoplos and Bernasek (1998) investigated whether women are different than men in risk aversion. Using survey of consumer finance 1989 they model the relative risk aversion on various variables such as wealth, race, age, education and other variables. Based on the theoretical link that suggest that risk aversion will decrease as the wealth increases it is found in this study that female risk aversion is not negatively related to wealth. They found that women are more risk averse than men leading to lower investment in risky assets than risk free assets.

Previous studies suggested that female are more risk averse and less confident than males, however the reasons behind these difference were not clarified. Graham, Stendardi, Myers and Graham (2002) used selectivity model to explain the gender behavior biases regarding investment. They concluded that women are more comprehensive in information processing than men. Males are found to be efficient in information processing when faced with low complexity task while women were more efficient when dealing with high complexity task. Male were found to follow more holistic process in information processing than women. Women on the other hand follow a more detailed information processing. Focusing more on fund manager than simply testing individuals, Beckerman and Menkhoff (2008) results pointed to the following. Females are less risk averse then males as fund managers, there was no difference between male and female fund managers in term of overconfidence, female fund managers avoid competition, financial expertise reduces gender differences however does not totally eliminate it.

\section{Regret}

Regret or anticipated regret is one of the factors that are associated with risk taking in behavioral economics. Regret could lead to either risk aversion or risk seeking. Inman and Zeelenberg (2002), Zeelenberg et al (1996), Zeelenberg and Beattie (1997) and Zeelenberg (1999) found evidences that support both risk seeking and risk aversion with regret is involved in decision making. The logic of the dual relationship is that people tend to embark in regret minimizing process whenever a decision has to be made. This regret minimizing theory lead people to either become risk averse or risk lover. In the regret minimizing-risk maximizing the relationship is established when the individual are asked to how future regret will influence their current decisions (i.e. how would you feel in the future if you made the wrong decision now?). People tend to shield themselves against future regret by avoiding risk now hence opt for the less risky decision. On the other hand, regret could lead to risk seeking behavior. This would happen if the individual is faced with two options or more where one is 
more risky than the others and there is always feedback on the outcome of the riskier option. Therefore if an individual faced with two choices where one is riskier than the other opting for the less risky option lead to regret if the riskier option turned out to be better than the less risky option (Larrick and Boles (1995) and Ritov (1996). However, the anticipated regret will disappear if there is no feedback on what would have been Boles and Messick (1995) and Ritov and Baron (1995).

\section{Overconfidence}

Barber and Odean (2000), Odean (1999) and Barber Odean (2001) found that investors trading too much will experience low returns even after controlling for tax loss selling rebalancing and other variables. They concluded in their paper barber and Odean (2001) that this phenomenon of trading too much and earning low returns can be explains by overconfidence. They claim that overconfident investors tend to overestimate the precision of the information leading them to overestimate their gains which cause them to trade too much and earning lower returns. There is also a link between individualism and overconfidence, which Markus and Kitayama (1991) describe as the tendency of of people in "individualistic cultures to think positively about themselves and focus on their own internal attributes, such as their abilities". Indeed, a large body of psychology literature find that individualistic cultures people, like the United States, believe that their abilities are above average, unlike people in collectivistic cultures, like Japan (Markus and Kitayama,1991; Heine et al.,1999). It also suggests that "people in individualistic cultures are likely to be more overconfident about the precision of their information than are people in collectivistic cultures". In addition, Baber and Odean (2001), Lundeberg, Fox and Puncochar (1994) found that there exist gender differences in overconfidence bias. Both men and women exhibit the overconfidence bias by trading excessively however, men tend to be more overconfident than women. Women being less overconfident than men can be linked to their risk aversion behavior in general.

Trust

Luhmann (1979) and Seligmen( 1997) indicated that there is a relationship between trust and risk taking, others argued that trusting is equal to risk taking (Yamagishi 2000). On the other hand, Luhmann $(1979,1988)$ suggested that risk must exist for trust to occur and when trust occur more risk will be attractive. This indicates that there is some kind of loop in the relationship between risk taking and trust. On the relationship between risk and trust, Siegrist (2000), Siegrest et al. (2000), Sjoberg (2001) and Viklund (2003), Olsen (2008) found that perceived risk is negatively related with trust, in other words, the lesser the trust the greater the perceived risk. Research also reveals that there is little or no correlation between one's decision to trust and one's overall level of risk aversion (Ashraf and Bohnet, 2006; Eckel and Wilson, 2004). However, according to Guiso et al. (2008) one's trust highly depends on his ethnic and religious background whereas Alesina and La Ferrara, (2002) found that differences in religion and ethnic origin do not significantly influence on the level of trust in most economically developed countries. 


\section{Luck and skill}

Zuckerman (1979) and Miller and Ross (1975) Fiske and Taylor (1991), Baumeister (1998), Duval and Silvia (2002) found that people tend to attribute success to their own skills and failures to bad luck. Blaine and Crocker (1993) found that individuals with high self-esteem believe they are lucky and tend to exaggerate their control over events, especially successful events. Camerer and Lovallo (1999) reported lower level of luck when skill is not accounted for. On the other hand, Armor \& Taylor 2002 indicate that greater uncertainty can induce greater optimism such that people become risk taker. Certainly, the inclusion of a skill component might increases risk taking. Put differently, if skill does not help in success, luck can ignite optimistic beliefs.

\section{Maximization}

Schwartz et al (2002) using Simon's (1957) concept of satisficer which is the mixture between satisfy and suffice studied the relations between maximization, regret, happiness, life satisfaction, and optimism among other variables. Using questionnaires they found that maximization was negatively related with happiness, optimism, self esteem and life satisfaction. On the other hand, maximization was positively related to depression, perfectionism and regret. Maximizers desire the best possible outcome while satisficer desire the outcome that is good enough. The result suggested that maximizes tend to regret more, look for perfection in their decision and depressed while they are less happy than satisficer, not very optimistic and have low level of self esteem and life satisfaction. This could be because maximizers are demanding investors and risk lover which lead them to expect higher returns on their investments.

\section{Happiness or life satisfaction}

Easterlin (1974) indicated that there was a positive relationship between happiness and individual income in the US. Easterlin (1995), Blanchflower and Oswald (2004) Frey and Stutzer (2002a), Graham and Pettinato (2002) and Layard (2005) found similar pattern in different countries such as France, the UK, Germany, Italy, Netherlands and Japan in different periods of time. Many studies have been done on the quality of life or life satisfaction however they tackle issues as goals, depression, personality and health. Few researches have used data connecting happiness and financial satisfaction such as Michalos (1991), Michalos and Orlando (2006) and Van Praag et al (2010). Although the relationship found between income and happiness was positive Easterlin (2001) and Frey and Stutzer (2002) indicated that there is no clear cut negative or positive relationship. Argyle (1999) in his book mentioned that higher income is associated with greater happiness, although the relation between income and happiness is stronger in relatively low-income countries than in relatively high-income countries such as the United States which was on average constant between 1942 and 1991 according to Antonio Falato (2008). Happiness seems to increase 
with income up to a certain point, but not beyond it. Isen and Patrick (1983) found that as the person become happier his reaction toward risk becomes lower.

\section{Data and Methodology}

The aim of this study is to investigate whether there is a significant difference in gender, religious affiliations, ethnicity and the country of origin with regard to risk taking propensity, regret, maximization, happiness trust and general risk taking. Previous studies on investor's behavior have largely utilized questionnaire survey for data collection. Considering that the study is interested in behavior and the first reactions that emerge when a scenario is presented a questionnaire survey is implemented as the method of data collection. The questions were adopted from Statman (2008) with the addition of only one question about general risk. Following Statman (2008) the questionnaire was distributed to Malaysian undergraduate students with business and finance majors in two public universities in Malaysia. The questionnaire was self administrated and collected immediately to capture the first thought and answers of the individual students. The total number of questionnaires distributed is 600 and the total number of usable questionnaire is 416 . Out of the 416 usable questionnaires, 350 are Malaysian respondents and 66 are foreign respondents.

\section{Results and Analysis}

This section reports and discusses the results of the study. Table 1 below shows the mean standard deviation of the variables measured. For the risk in income (portfolio) question, the result is to indicate that if the respondent is willing to take a risk in his/her lifetime income (portfolio) how much will that be compared to a guaranteed $50 \%$ gain with the current income (portfolio). The mean of lifetime income risk is a little higher at 11.32 this indicate that on average Malaysian are willing to risk their lifetime income only if the upside is five times larger than 11.32. On the other hand, the risk on portfolio on average is higher at 12.41 though the two questions are phrased in the same manner. Statman (2008) explained that could happen because investors tend to think of their money in layers where portfolio income is in a higher layer than job income. Standard deviation of both risk questions are 7.64 for income risk and 7.15 for portfolio risk. In addition, Malaysian seems to have high propensity of regret at 6.8 and maximization at 6.52 similar to the finding of Statman (2008). High level of happiness is found among Malaysians at almost 6.8 while in terms of trust they were lower at 4.43. Lastly the general level of risk taking for Malaysian investors seems to be modest at 5.23. The standard deviations indicate that there is variability in the responses ranging between 1.87 and 2.41 .

Table 1 descriptive statistics 


\begin{tabular}{|l|l|l|}
\hline Variables & Mean & Std. Deviation \\
\hline Risk in income & 11.32 & 7.6 \\
\hline Risk in portfolio & 12.41 & 7.15 \\
\hline Luck & 3.9 & 2.2 \\
\hline Overconfidence & 5.8 & 1.9 \\
\hline Regret & 6.8 & 2.1 \\
\hline Maximize & 6.5 & 2.4 \\
\hline Happiness & 6.77 & 1.9 \\
\hline Trust & 4.4 & 2.2 \\
\hline Risk & 5.2 & 1.9 \\
\hline
\end{tabular}

Table 2 reports the demographic of the respondents. Majority of the respondents (72\%) were female, $78 \%$ were Muslims and $76.3 \%$ were Malay. The second highest religion is Buddhism at $17 \%$ followed by Christianity at 2.6 and lastly Hinduism at 2. In terms of race, the second highest is Chinese at $20.6 \%$ and followed by Indians and others at $3.1 \%$.

Table 2 demographic profile of the respondents

\begin{tabular}{|c|c|c|}
\hline & & Percentage \\
\hline \multirow[t]{2}{*}{ Sex } & Female & $72 \%$ \\
\hline & Male & $28 \%$ \\
\hline \multirow[t]{4}{*}{ Religion } & Islam & $78 \%$ \\
\hline & Buddhism & $17 \%$ \\
\hline & Christianity & $3 \%$ \\
\hline & Hinduism\& Others & $2 \%$ \\
\hline \multirow[t]{3}{*}{ Race } & Malay & $76 \%$ \\
\hline & Chinese & $21 \%$ \\
\hline & Indian \& Others & $3 \%$ \\
\hline
\end{tabular}

Table 3 reports the results of the significant difference between Malaysian Malay males (MMM) and females (MMF) in term of all the variables. The results suggest that Malay males score higher means than female in overconfidence and Maximization while the opposite is true with regard to luck and the general level of risk. This indicates that MMM and MMF believe in skill over luck when thinking about investment. In addition, MMM and MMF are somewhat mildly overconfident when picking stocks. Both MMM and MMF are 
outcome maximizers in the sense they aim for the best outcome in their investment which indicate that they are rational investors. Lastly, MMM and MMF tend fall in the middle of the general risk level. This implies that even though one group might score higher than the other in specific risk they tend to be close to the center in general risk. Therefore, a profile can be derived from this information. MMF and MMM consider themselves skillful, have mild overconfidence, somewhat rational and risk neutral in general.

Table 3 differences between Malaysian Malay race in term of gender

\begin{tabular}{|l|l|l|l|l|}
\hline & $\begin{array}{l}\text { Male } \\
\text { Malay } \\
\text { Mean }\end{array}$ & $\begin{array}{l}\text { Female Malay } \\
\text { Mean }\end{array}$ & $\begin{array}{l}\text { Mean } \\
\text { Difference }\end{array}$ & t-value \\
\hline $\begin{array}{l}\text { Risk tolerance in } \\
\text { income }\end{array}$ & 11.73 & 11.23 & -0.500 & -0.478 \\
\hline $\begin{array}{l}\text { Risk tolerance in } \\
\text { portfolio }\end{array}$ & 12.30 & 12.38 & 0.074 & 0.076 \\
\hline Luck & 3.27 & 4.1 & $0.765^{*}$ & 2.90 \\
\hline Overconfidence & 6.01 & 5.5 & $-0.514^{* *}$ & 2.15 \\
\hline Regret & 7.28 & 6.87 & -0.411 & -1.625 \\
\hline Maximization & 7.16 & 6.26 & $-0.909^{*}$ & -2.875 \\
\hline Happiness & 6.82 & 6.78 & -0.046 & -0.186 \\
\hline Trust & 4.52 & 4.22 & -0.296 & -0.900 \\
\hline Risk & 4.85 & 5.36 & $.508^{* *}$ & 1.978 \\
\hline
\end{tabular}

$*$ and $* *$ significant at $1 \%$ and $5 \%$ respectively

The results in table 4 below indicate a significant difference between Malaysian Chinese male $(\mathrm{MCM})$ and females $(\mathrm{MCF})$ in terms of risk tolerance in portfolio, maximization and trust. MCM mean of portfolio risk propensity is higher than MCF however they both fall between $12 \%$ and $16 \%$. This reflects that MCM and (MCF) are willing to risk their portfolio only if the benefit to the standard of living is approximately five times larger than the $15.6 \%(12.4 \%)$ losses. Both MCM and MCF are maximizers in their outcomes though MCM score higher than MCF. Moreover, MCM believe people should not be trusted while MCF lean more towards trusting people. Therefore, MCM and MCF are mildly risk taker in portfolio and somewhat highly rational but differ in trust where the former is less trusting while the latter is more trusting. 
Table 4 differences between Malaysian Chinese race in term of gender

\begin{tabular}{|l|l|l|l|l|}
\hline & $\begin{array}{l}\text { Male Chinese } \\
\text { Mean }\end{array}$ & $\begin{array}{l}\text { Female Chinese } \\
\text { Mean }\end{array}$ & Mean Difference & t-value \\
\hline Risk tolerance in income & 12.19 & 11.09 & -1.098 & -.522 \\
\hline Risk tolerance in portfolio & 15.56 & 12.38 & $-3.188^{* * *}$ & -1.651 \\
\hline Luck & 3.62 & 4.27 & 0.643 & 1.025 \\
\hline Overconfidence & 6.69 & 6.1 & -0.59 & -1.33 \\
\hline Regret & 5.44 & 6.09 & 0.652 & .966 \\
\hline Maximization & 7.38 & 6.09 & $-1.286^{* * *}$ & -1.808 \\
\hline Happiness & 6.00 & 6.73 & 0.732 & .998 \\
\hline Trust & 3.69 & 5.39 & $1.705^{*}$ & 2.784 \\
\hline Risk & 5.19 & 5.25 & 0.063 & .131 \\
\hline
\end{tabular}

$*$ and $* * *$ significant at $1 \%$ and $10 \%$ respectively

In term of Malaysian Indians table 5 below report the results. No significant difference is found in any of the variables studied.

Table 5 differences between Malaysian Indian in term of gender

\begin{tabular}{|l|l|l|l|l|}
\hline & $\begin{array}{l}\text { Male } \\
\text { Indian } \\
\text { Mean }\end{array}$ & $\begin{array}{l}\text { Female Indian } \\
\text { Mean }\end{array}$ & $\begin{array}{l}\text { Mean } \\
\text { Difference }\end{array}$ & t-value \\
\hline $\begin{array}{l}\text { Risk tolerance in } \\
\text { income }\end{array}$ & 11.00 & 9.38 & -1.625 & -0.403 \\
\hline $\begin{array}{l}\text { Risk tolerance in } \\
\text { portfolio }\end{array}$ & 9.00 & 9.38 & 0.375 & 0.103 \\
\hline Luck & 4 & 3.88 & -0.125 & -0.072 \\
\hline Overconfidence & 7 & 5.75 & -1.25 & -0.744 \\
\hline Regret & 6.67 & 7.00 & 0.333 & 0.297 \\
\hline Maximization & 7.33 & 7.50 & 0.167 & 0.119 \\
\hline Happiness & 8.00 & 7.25 & -0.750 & -0.558 \\
\hline Trust & 3.67 & 3.63 & -0.042 & -0.017 \\
\hline Risk & 6.67 & 5.50 & -1.167 & -0.905 \\
\hline
\end{tabular}

Tables 6, 7, 8 and 9 report the mean difference between male and females for the four religious affiliations. Similar to the tables 3,4 and 5 these tables report the interactions 
between religion and gender to see whether the trends appearing between males and females reported in table 3 are confirmed.

Malaysian Muslim males score higher means in all the other variables except for Luck and general risk level where females score higher. A significant difference is found between Muslim males and females with regard to luck, overconfidence, maximization and general risk level. Results in table 6 replicate result in table 3. This is true because Malay and Muslims are synonym in Malaysia.

Table 6 differences between Malaysian Muslims in term of gender

\begin{tabular}{|l|l|l|l|l|}
\hline & $\begin{array}{l}\text { Male } \\
\text { Muslim } \\
\text { Mean }\end{array}$ & $\begin{array}{l}\text { Female Muslim } \\
\text { Mean }\end{array}$ & $\begin{array}{l}\text { Mean } \\
\text { Difference }\end{array}$ & t-value \\
\hline $\begin{array}{l}\text { Risk tolerance in } \\
\text { income }\end{array}$ & 11.73 & 11.23 & -.444 & -0.431 \\
\hline $\begin{array}{l}\text { Risk tolerance in } \\
\text { portfolio }\end{array}$ & 12.38 & 12.31 & .083 & 0.087 \\
\hline Luck & 3.32 & 4.07 & $0.75^{* *}$ & 2.6 \\
\hline Overconfidence & 6.01 & 5.53 & $-0.48^{* * *}$ & -1.91 \\
\hline Regret & 7.23 & 6.86 & -.374 & -1.501 \\
\hline Maximization & 7.15 & 6.24 & $-.905^{*}$ & -2.914 \\
\hline Happiness & 6.86 & 6.79 & -.077 & -0.314 \\
\hline Trust & 4.54 & 4.21 & -.331 & -1.024 \\
\hline Risk & 4.91 & 5.37 & $.459^{* *}$ & 1.810 \\
\hline
\end{tabular}

* and ** significant at $1 \%$ and $5 \%$ respectively

Table 7 reports results for Malaysian Christians. Malaysian Female Christians (MFC) differ significantly from Malaysian Male Christian (MMC) in term of trust. MMC are less trusting while MFC are more trusting.

Table 7 differences between Malaysian Christian in term of gender

\begin{tabular}{|l|l|l|l|l|}
\hline & $\begin{array}{l}\text { Male Christian } \\
\text { Mean }\end{array}$ & $\begin{array}{l}\text { Female } \\
\text { Christian } \\
\text { Mean }\end{array}$ & $\begin{array}{l}\text { Mean } \\
\text { Difference }\end{array}$ & t-value \\
\hline $\begin{array}{l}\text { Risk tolerance in } \\
\text { income }\end{array}$ & 15.00 & 13.00 & -2.000 & -0.350 \\
\hline $\begin{array}{l}\text { Risk tolerance in } \\
\text { portfolio }\end{array}$ & 19.50 & 18.00 & -1.500 & -0.235 \\
\hline Luck & 3.5 & 5 & 1.5 & 0.716 \\
\hline Overconfidence & 6.67 & 6 & -0.67 & -0.45 \\
\hline
\end{tabular}




\begin{tabular}{|l|l|l|l|l|}
\hline Regret & 6.00 & 5.67 & -.333 & -0.137 \\
\hline Maximization & 7.83 & 9.33 & 1.500 & 0.942 \\
\hline Happiness & 6.00 & 9.00 & 3.000 & 1.197 \\
\hline Trust & 3.33 & 6.67 & $3.333^{* * *}$ & 1.800 \\
\hline Risk & 5.67 & 3.33 & -2.333 & -1.416 \\
\hline
\end{tabular}

*** significant at $10 \%$.

Table 8 reports the results for the interaction between sexes in term of Malaysian Buddhist. Malaysian Buddhist Males (MBM) and Malaysian Buddhist Females (MBF) are significantly different in term of overconfidence and trust. Both MBM and MBF are somewhat overconfident when picking their stocks for investment. MBM believe that people should not be trusted while the opposite is true for MBF while they believe fairly that people should be trusted.

Table 8 differences between Malaysian Buddhist in tem of gender

\begin{tabular}{|l|l|l|l|l|}
\hline & $\begin{array}{l}\text { Male } \\
\text { Buddhist } \\
\text { Mean }\end{array}$ & $\begin{array}{l}\text { Female } \\
\text { Buddhist } \\
\text { Mean }\end{array}$ & $\begin{array}{l}\text { Mean } \\
\text { Difference } \\
\text { t-test }\end{array}$ & t-value \\
\hline $\begin{array}{l}\text { Risk tolerance in } \\
\text { income }\end{array}$ & 11.25 & 10.65 & -0.603 & -0.215 \\
\hline $\begin{array}{l}\text { Risk tolerance in } \\
\text { portfolio }\end{array}$ & 14.63 & 11.88 & -2.743 & -1.146 \\
\hline Luck & 4 & 4.1 & 0.098 & 0.123 \\
\hline Overconfidence & 7.38 & 6.1 & $-1.227 *$ & -2.27 \\
\hline Regret & 5.38 & 6.08 & 0.703 & 0.799 \\
\hline Maximization & 7.13 & 5.92 & -1.203 & -1.265 \\
\hline Happiness & 6.50 & 6.61 & 0.108 & 0.164 \\
\hline Trust & 3.88 & 5.31 & $1.439 * * *$ & 1.752 \\
\hline Risk & 4.88 & 5.33 & 0.458 & 0.758 \\
\hline
\end{tabular}

*** Significant at $10 \%$.

Table 9 reports the results for the interaction between sexes in term of Malaysian Hindus. Hindus males and females are not significantly different in any of the variables.

Table 9 differences between Malaysian Hindus in term of gender

\begin{tabular}{|l|l|l|l|l|}
\hline & $\begin{array}{l}\text { Male } \\
\text { Hindu } \\
\text { Mean }\end{array}$ & $\begin{array}{l}\text { Female Hindu } \\
\text { Mean }\end{array}$ & $\begin{array}{l}\text { Mean Difference } \\
\text { t-test }\end{array}$ & -value \\
\hline
\end{tabular}




\begin{tabular}{|l|l|l|l|l|}
\hline Risk tolerance in income & 9 & 12 & 3 & 0.51 \\
\hline Risk tolerance in portfolio & 6 & 12 & 6 & 1.26 \\
\hline Luck & 2 & 5 & 3 & 1.42 \\
\hline Overconfidence & 7 & 4.8 & -2.2 & -0.95 \\
\hline Regret & 6.5 & 7.4 & 0.9 & 0.36 \\
\hline Maximization & 9 & 8.4 & -0.6 & -0.89 \\
\hline Happiness & 5.5 & 7 & 1.5 & 0.78 \\
\hline Trust & 2.5 & 4.2 & 1.7 & 0.57 \\
\hline Risk & 5 & 5.2 & 0.2 & 0.21 \\
\hline
\end{tabular}

Table 10 reports the results for the interaction between sexes in term of non-Malaysian. Foreign males and females are significantly different in lifetime risk propensity and luck. This indicate that male foreigners and (female foreigners) are willing to risk their portfolio only if the benefit to the standard of living is approximately five times larger than the $12.2 \%$ (9.2\%) losses. This shows that females are risk averse compare to male foreigners though both of them are in the low spectrum of the acceptable risk level. Both male and female foreigners rely on skill than luck when investing in stocks though male falls more towards the middle point than females who are fall closer to using skill than luck.

Table 10 differences between non-Malaysian in term of gender

\begin{tabular}{|l|l|l|l|l|}
\hline & $\begin{array}{l}\text { Male } \\
\text { non-Malaysian } \\
\text { Mean }\end{array}$ & $\begin{array}{l}\text { Female } \\
\text { non-Malaysian } \\
\text { Mean }\end{array}$ & $\begin{array}{l}\text { Mean Difference } \\
\text { t-test }\end{array}$ & t-value \\
\hline Risk tolerance in income & 12.18 & 9.19 & $-2.99 * * *$ & -1.81 \\
\hline Risk tolerance in portfolio & 13.18 & 11.53 & -1.651 & -0.92 \\
\hline Luck & 4.67 & 3.44 & $-1.22^{*}$ & -2.3 \\
\hline Overconfidence & 6.03 & 5.97 & -0.062 & -0.13 \\
\hline Regret & 6.58 & 6.69 & .112 & 0.20 \\
\hline Maximization & 6.39 & 7.09 & .70 & 1.22 \\
\hline Happiness & 8.12 & 7.63 & -.496 & -1.12 \\
\hline Trust & 4.39 & 4.41 & .012 & 0.021 \\
\hline Risk & 5.39 & 5.34 & -.05 & -0.093 \\
\hline
\end{tabular}

$*$ and $* * *$ significant at $1 \%$ and $10 \%$ respectively

\section{Discussion and Conclusion}

Malaysian Malay males and females are significantly different in luck, overconfidence, maximization and general level of risk. Malaysian males and females believe more on skill when investing, are somewhat overconfident, tend to maximize the outcome of each decision, and are fairly risk averse. Malaysian Chinese have a different profile. Malaysian Chinese 


\section{Macrothink}

male and female differ in their propensity towards portfolio risk where males are more risk taker than females. In addition, Chinese males tend to aim for the best outcome than females. Malaysian Indians do not have any significant difference in any of the variables.

When religion is added to look at how religious affiliation might influence investment decisions the result for Malaysian Muslims replicate the results of Malaysian Malay. On the other hand, Christian males and females tend to differ in term of trust where males believe that most people should not be trusted and females believe that most people should be trusted. Buddhist males and females are different in overconfidence and happiness. Both are somewhat overconfident but males are untrusting while females are trusting. Hindus do not differ in any of the variables.

Lastly, male and female foreign students differ in their propensity towards lifetime income risk and their belief of the element of luck. Males tend to be risk taker and believe in luck over skill then female.

In short, in general Malaysians fall in the middle spectrum of risk propensity in both portfolio and lifetime income. In addition, Malaysians seem to rely on their skills in picking their investments than relying on luck, they somewhat are overconfident in their choices, have to some extent high level of regret. Moreover, Malaysians are maximizers or rational investor focusing more on cost and benefit rather than other variables, considered to be fairly happy, quite cautious where they believe people cannot be trusted and generally are risk neutral. Finally foreigners do not seem to differ much from Malaysian in general.

Therefore, investment managers should consider these differences when approaching investors since different investors have different beliefs and race and religion have significant influence on the perception of investors' abilities. 


\section{References}

Alesina, A. and La Ferrara, E., (2002). "Who trusts others?" Journal of Public Economics, Elsevier, vol. 85, no. 2, 207-234.

Argyle, M. (1999). "Causes and Correlates of Happiness." In Kahneman, D., E. Diener and N. Schwarz (eds.):Well-Being: The Foundations of Hedonic Psychology, Russel Sage Foundation, New York: pp. 353-373.

Armor, D.A. \& Taylor, S.E. (2002). When predictions fail: The dilemma of unrealistic optimism. In T. Gilovich, D. Griffin, \& D. Kahneman (Eds.), Heuristics and Biases: The Psychology of Intuitive Judgment (pp. 334-347). New York, NY: Cambridge University Press.

Arruñada, B. (2009), "Specialization and Rent-Seeking in Moral Enforcement: The Case of Confession," Journal for the Scientific Study of Religion, 48(3), 443-61.

Ashraf, N., Bohnet, I., Piankov, N. (2006). Decomposing trust and trustworthiness. Experimental economics, vol. 9, 193-208.

Barber, B. M. and Odean, T. (2000) Trading is hazardous to your wealth: The common stock investment performance of individual investors. The Journal of Finance, vol. 55, no. 2, 773-806.

Barber, B. M. and Odean, T. (2001). Boys Will Be Boys: Gender, Overconfidence, and Common Stock Investment, Quarterly Journal of Economics. 116(1): 261-292.

Baumeister, R. F. (1998): "The Self," in The Handbook of Social Psychology, ed. by D. T. Gilbert, S. T. Fiske, and G. Lindzey. McGraw-Hill, New York.

Beckmann, D. and Menkhoff, L. (2008) Will Women Be Women? Analyzing the Gender Difference among financial experts. KYKLOS, Vol. 61, No. 3, 364-384.

Beugelsdijk, S. and Frijns, B. (2010). A cultural explanation of the foreign bias in international asset allocation. Journal of Banking and Finance, vol. 34, 2121-2131.

Blaine, B., and J. Crocker (1993): "Self-esteem and Self-serving Biases in Reactions to Positive and Negative Events: An Integrative Review," in Self-esteem: The Puzzle of Low Self-regard, ed. by R. Baumeister. Plenum, New York

Blanchflower, David and Andrew J. Oswald. 2004. "Well-Being over Time in Britain and the USA.” Journal of Public Economics. 88:7-8, pp. 1359-386.

Boles, T. L., \& Messick, D. M. (1995). Reverse outcome bias: the influence of multiple reference points on the evaluations of outcomes and decisions. Organizational Behavior and Human Decision Processes, 61, 262-275.

Camerer, C. and Lovallo, D. (1999). Overconfidence and Excess Entry: An Experimental Approach. The American Economic Review, vol. 89, no. 1, 306-318.

CHUI, A. C.W., TITMAN, S. and WEI, K.C. J. (2010), Individualism and Momentum around the World. The Journal of Finance, vol. 65, no. 1, 361-392.

Duval, T. S., and P. J. Silvia (2002): "Self-Awareness, Probability of Improvement, and the Self-serving Bias," Journal of Personality and Social Psychology, 82, 49- 61.

Easterlin, R. (2001). "Income and Happiness: Towards a Unified Theory." Economic Journal, vol. 111, no. 473, 465-84.

Easterlin, Richard. 1974. "Does Economic Growth Improve the Human Lot? Some Empirical 
Evidence," in Nations and Households in Economic Growth: Essays in Honour of Moses Abramovitz. P. David and M. Reder, eds. New York and London: Academic Press, pp. 98-125.

Easterlin, Richard. 1995. "Will Raising the Incomes of All Increase the Happiness of All?" Journal of Economic Behavior and Organization. 27:1, pp. 35-48.

Eckel, C. C., Wilson, R. K. (2004). Is trust a risky decision? Journal of Economic Behavior \& Organization, vol. 55, 447-465.

Falato, A. (2009). "Happiness Maintenance and Asset Prices," Journal of Economic Dynamics and Control, vol. 33, no. 6, pp. 1247-1262.

Falato, Antonio (2009). "Happiness Maintenance and Asset Prices," Journal of Economic Dynamics and Control, vol. 33, no. 6, pp. 1247-1262.

Frey, B. and Alois S. 2002. "What Can Economists Learn from Happiness Research?" Journal of Economic Literature. 40:2, pp. 402-35.

Graham, Carol and Stefano Pettinato. 2001. Happiness and Hardship: Opportunity and Insecurity in New Market Economies. Washington, D.C.: Brookings Institution Press.

Graham, J. F., Stendardi, E. J., Myers, J. K., and Graham, M. J. (2002). Gender differences in investment strategies: an information processing perspective. International journal of bank marketing, vol.20, no.1, 17-26.

Guiso, L. and Paiella, M. (2003). "Risk Aversion, Wealth and Background Risk," Temi di discussione (Economic working papers) 483, Bank of Italy, Economic Research and International Relations Area.

Guiso, L., Sapienza, P. and Zingales, L. (2008), Alfred Marshall Lecture - Social Capital as Good Culture, Journal of the European Economic Association, vol. 6(2-3), 295-320.

Guiso, L., Sapienza, P., and Zingales, L. (2006). Does Culture Affect Economic Outcomes? Journal of Economic Perspectives, vol. 20, no. 2, 23-48.

Hilary, G., Hui, K.W., 2009. Does religion matter in corporate decision making in America? Journal of Financial Economics, vol. 93, 455-473.

Hong, B. K., Chan, K., and Ng, A. (2004). Invisibility and return volatility, Journal of Financial Economics 71, 239-263.

Huang, P. H. (2008). How do Securities Laws Influence Affect, Happiness, \& Trust? Journal Of Business \& Technology Law, 257-308.

Inman, J.J., \& Zeelenberg, M., (2002). Regret repeat versus switch decisions: The attenuation role of decision justifiability. Journal of Consumer Research, 29, 116-128.

Isen, A. M., \& Patrick, R. (1983). The effect of positive feelings on risk taking: When the chips are down. Organizational Behavior and Human Decision Processes, 31, 194-202.

Jianakoplos, N. and Bernasek, A. (1998). Are women more risk averse? Economic inquiry, vol. 36, 620-630.

Kumar, A., Page, J. K., and Spalt, O. G. (2011). Religious Beliefs, Gambling Attitudes, and Financial Market Outcomes. EFA 2009 Bergen Meetings Paper; Journal of Financial Economics (JFE), Forthcoming. Available at SSRN: http://ssrn.com/abstract=1335855

Larrick, R. P., \& Boles, T. L. (1995). Avoiding regret in decisions with feedback: A negotiation example. Organizational Behavior and Human Decision Processes, 63, 87-97.

Luhmann, N. (1979) Trust and power. Chichester, UK: John Wiley \& sons. 


\section{Macrothink}

Journal of Sociological Research

ISSN 1948-5468

2012, Vol. 3, No. 2

Luhmann,N. (1988).Familiarity, confidence, trust:Problems and al- ternatives. In D. Gambetta (Ed.), Trust: Making and Breaking Cooperative Relations (pp. 94-108). Oxford: Basil Blackwell.

Lundeberg, Mary A., Paul W. Fox and Judith Punccohar (1992). Highly Confident but Wrong, Gender Differences and Similarities in Confidence Judgments, Journal of Educational Psychology. Vol. 86, no.1, 114-121.

Michalos, A.C. and J.A. Orlando: 2006, "A note on student quality of life", Social Indicators Research, 79(1), pp.51-59.

Michalos, A.C.: 1991, Global Report on Student Well-Being: Volume 1, Life Satisfaction and Happiness, Springer-Verlag, New York.

Miller, D., and M. Ross (1975): "Self-serving Biases in the Attribution of Causality: Fact or Fiction?” Psychological Bulletin, 82, 213- 225.

Odean, T. (1999). Do investors trade too much? American economic review, vol. 89, no. 5, 1279-1298

Olsen R. A. (2008). Trust as risk and the foundation of investment value. The Journal of Socio-Economics, vol. 37, 2189-2200.

Ritov, I. (1996). Probability of regret: anticipation of uncertainty resolution in choice. Organizational Behavior and Human Decision Processes, 66, 228-236.

Ritov, I., \& Baron, J. (1995). Outcome knowledge, regret, and omission bias. Organizational Behavior and Human Decision Processes, 64, 119-127.

Statman, M. (2008), 'Countries and culture in behavioral finance', CFA Institute Conference Proceedings Quarterly 25(3).

Schwartz, B.,Ward, A., Monterosso, J., Lyubomirsky, S., White, K., \& Lehman, D. R. (2002). Maximizing versus satisficing: Happiness is a matter of choice. Personality and Social Psychology, 83, 1178-1197.

Seligman, A. B. (1997). The Problem of Trust. Princeton, NJ: Princeton University press.

Siegrist, M. (2000). The influence of trust and perceptions of risks and benefits on acceptance of gene technology. Risk analysis, vol. 20, no. 2, 195-203.

Siegrist, M., Cvetkovich, G. (2000). Salient Value Similarity, Social Trust, and Risk/Benefit Perception. Risk Analysis, Vol. 20, No. 3,

Siegrist, M., Cvetkovich, G., \& Roth, C. (2000). Salient value similarity, social trust, and risk/ benefit perception. Risk Analysis, 20, 353-362.

Simon, H. A. (1955). Behavioral model of rational choice. Quarterly journal of economics, vol. 59, 99-118.

Sjoberg, L. (2001). Limits of knowledge and the limited importance of trust. Risk Analysis, vol. 21, no. 1, 189-198.

Van Praag, B. M. S., Romanov, D., Carbonellc, A. F. (2010) Happiness and financial satisfaction in Israel: Effects of religiosity, ethnicity, and war. Journal of Economic Psychology, vol. 31, no. 1, 1008-1020.

Viklund, M. (2003). Trust and risk perception in Western Europe: a cross-national study. Risk analysis, vol. 23, no. 4, 727-738.

Wan Ahmad, W.M., A. Ab Rahman, N.A. Ali and A. Che Seman, 2008. Religiosity and Banking Selection Criteria among Malays in Lembah Klang. Shariah J., 16(2): 79-84. 
Worthington, E. L., Wade, N. G., Hight, T. L., McCullough, M. E., Berry, J. T., Ripley, J. S. et al. (2003). The religious commitment inventory-10: development, refinement and validation of a brief scale for research and counseling. Journal of Counseling Psychology, 50, 84-96.

Yamagishi, T. (2000). Session on Trust at the 27th International Congress of Psychology, Stockholm, Sweden, July 23-28, 2000.

Zeelenberg, M. (1999). Anticipated regret, expected feedback and behavioral decision-making. Journal of Behavioral Decision Making, 12, 93-106.

Zeelenberg, M., \& Beattie, J. (1997). Consequences of regret aversion 2: Additional evidence for effects of feedback on decision making. Organizational Behavior and Human Decision Processes, 67, 63-78.

Zeelenberg, M., Beattie, J., van der Pligt, J., \& de Vries, N. K. (1996). Consequences of regret aversion: Effects of expected feedback on risky decision making. Organizational Behavior and Human Decision Processes, 65, 148-158.

Zeelenberg, M., van Dijk, W. W., van der Pligt, J., Manstead, A. S. R., van Empelen, P., \& Reinderman, D. (1998). Emotional reactions to the outcomes of decisions: The role of counterfactual thought in the experience of regret. Organizational Behavior and Human Decision Processes, 75, 117-141.

Zuckerman, M. (1979): “Attribution of success and failure revisited, or: The motivational bias is alive and well in attribution theory," Journal of Personality, 47, 245- 287. 